\title{
JOLANTA LIPIŃSKA-LOKŚ
}

Uniwersytet Zielonogórski, Uniwersytet Wrocławski

\section{Rodzice wobec wyboru formy kształcenia dziecka z niepełnosprawnością}

\begin{abstract}
Jolanta Lipińska-Lokś, Rodzice wobec wyboru formy ksztatcenia dziecka $z$ niepetnosprawnościa [Parents against choosing a form of education for a child with a disability]. Interdyscyplinarne Konteksty Pedagogiki Specjalnej, nr 22, Poznań 2018. Pp. 305-321. Adam Mickiewicz University Press. ISSN 2300-391X. DOI: https://doi. org/10.14746/ikps.2018.22.17

The law in the situation of a child with disability acquires particular importance, especially in the matter of choosing the form of its education. Whether they will choose a special school or an integration class for their child, or maybe they will think about inclusive education - it is conditioned by many factors, and each of them can be the most important for a particular parent. The subject of the presented research message was made the opinions and experiences of parents in the area of choosing form of education for a child with disability. The settles of their earlier decisions and the level of accuracy of choice were determined thanks to the assessment of a given form of education by the parents.
\end{abstract}

KEY WORDS: parents of a child with disability, student with disability, forms of special education

\section{Wprowadzenie}

Każde dziecko ma niepodważalne prawo do nauki, która ma służyć jego rozwojowi i przygotowaniu do życia w odpowiednich dla niego warunkach ${ }^{1}$. W określonym wieku ma poddać się także

${ }^{1}$ Konwencja o prawach dziecka, przyjęta przez Zgromadzenie Ogólne Narodów Zjednoczonych z dnia 20 listopada 1989 r., Dz.U. 1991, Nr 120, poz. 526. 
powinności wypełniania obowiązku szkolnego. Realizacji praw i obowiązków dziecka służą unormowania prawne (ustawa i odpowiednie rozporządzenia) ${ }^{2}$. Zabezpieczenie praw dziecka stanowi obowiązek instytucji państwa oraz jego rodziców. Wypełnianie powinności wobec dziecka z mocy prawa poddawane jest ocenie. Rodzice mają tego faktu świadomość, zaniedbanie względem dziecka może skutkować ograniczeniem lub pozbawieniem ich władzy rodzicielskiej. Zdają sobie sprawę także $\mathrm{z}$ posiadanych praw przysługujących im $\mathrm{z}$ racji bycia rodzicem, decydowania o swoim dziecku. Niestety w konkretnych sytuacjach nie o wszystkich swych prawach wiedzą czy pamiętają, nie ze wszystkich $\mathrm{w}$ pełni korzystają. $\mathrm{W}$ obszarze edukacji dziecka wymaga się od rodzica zapewnienia dziecku realizacji obowiązku szkolnego: zgłoszenia dziecka do szkoły, zapewnienia mu uczęszczania do niej i przygotowania się do zajęć. Ma też szereg praw związanych z posiadaniem dziecka - ucznia. Ma możliwość uczestniczyć w życiu jego szkoły i być partnerem $w$ interakcji z nauczycielami. Ma przede wszystkim prawo decydować o swoim dziecku w murach szkoły, w jego edukacji, m.in. w wyborze formy jego kształcenia. Decyzję tę ustawodawca pozostawił rodzicom, co mocno podkreślane jest $\mathrm{w}$ unormowaniach prawnych oraz $\mathrm{w}$ literaturze przedmiotu: „(..) zawsze decyzję o ścieżce edukacyjnej dziecka podejmują rodzice. Współcześnie wskazanie o potrzebie kształcęnia specjalnego nie jest już związane z miejscem jej realizacji"3. Tak więc tę ostateczną decyzję o formie kształcenia dziecka podejmuje rodzic.

2 Ustawa o systemie oświaty z 7 września 1991 r., tekst jednolity, Dz.U. 2004, Nr 256, poz. 2572. Ustawodawca w trosce o poszczególne obszary funkcjonowania placówek oświatowych, kwalifikacji osób w nich zatrudnionych oraz postępowania wobec dzieci i młodzieży tam przebywających ustanawia przepisy szczegółowe $\mathrm{w}$ postaci rozporządzeń. Pojawia się refleksja autorki o z jednej strony potrzebie zmian przepisów, z drugiej o pewnym braku poczucia bezpieczeństwa w związku ze zmianami osób, których te zmiany dotyczą.

${ }^{3}$ I. Chrzanowska, Pedagogika specjalna. Od tradycji do wspótczesności, Oficyna Wydawnicza „Impuls”, Kraków 2015, s. 590. 
Decyzja ta ma ogromne znaczenie z uwagi na rozwój i samopoczucie dziecka. Przy założeniu, że rodzic najlepiej zna swoje dziecko i otrzyma wsparcie ze strony specjalistów, ma on możliwość ocenić, w jakim środowisku dziecko ma największe szanse rozwoju i będzie czuło się bezpiecznie. Niewątpliwie jest to decyzja trudna, złożona, uwarunkowana wieloma czynnikami. Wśród tych czynników najczęściej przez rodziców wymienianych znalazły się: stosunek rodziców do danej formy kształcenia, istniejące możliwości i ograniczenia oraz doświadczenia rodziców. Poza tym wskazuje się na wiele czynników natury ogólnej warunkujących wybór formy kształcenia ucznia z niepełnosprawnością, m.in. system orzekania o specjalnych potrzebach edukacyjnych i sposobach ich zaspokajania, system finansowania kształcenia specjalnego, czynniki demograficzne i przestrzenne, kwestie etyczne i kulturowe ${ }^{4}$. Istotne znaczenie nadaje się niewątpliwie możliwości decydowania rodziców o wyborze kształcenia ich dziecka. Traktuje się tę kwestię jako sytuację naturalną z uwagi na prawa rodziców i ich odpowiedzialność za dziecko. Dostrzega się równocześnie zagrożenie, jakie niesie brak merytorycznego przygotowania rodzica w obszarze edukacji ucznia z niepełnosprawnością. Nie brak i głosów, że tak wiele praw rodziców do decyzji o losach edukacyjnych ich dziecka może „w skrajnych przypadkach prowadzić do naruszenia dobrze pojętego interesu ucznia niepełnosprawnego" ${ }^{2}$. Zachodzi więc uzasadniona obawa, że rodzice lękając się zmian w życiu dziecka spowodowanych diagnozą i orzeczeniem albo stereotypu złej szkoły specjalnej, nie posiadając jednocześnie wystarczającej wiedzy oraz wsparcia czy też kierując się doświadczeniami innych rodziców - podejmą niekorzystną dla swego dziecka decyzję o jego drodze edukacyjnej.

Nie bez znaczenia w podjęciu decyzji o wyborze formy edukacji dziecka z niepełnosprawnością jest z pewnością ich liczba i zróżni-

${ }^{4}$ A. Zamkowska, Wsparcie edukacyjne uczniów z upośledzeniem umysłowym w stopniu lekkim w różnych formach kształcenia na I etapie edukacji, Politechnika Radomska, Wydawnictw, Radom 2009.

5 Ibidem, s. 56. 
cowanie. Należy pamiętać, że system kształcenia specjalnego stanowi integralną część systemu oświaty w Polsce. Obecnie dziecko z niepełnosprawnością może realizować obowiązek szkolny w trzech typach szkół: specjalnej, integracyjnej i ogólnodostępnej. Wybór szkoły „powinien być poprzedzony rzetelną diagnozą jego potrzeb i możliwości oraz uwzględniać decyzje rodziców lub opiekunów prawnych"6. Jest to sprawa ważna z uwagi na fakt, iż „osoby z niepełnosprawnością, o zaburzonym rozwoju mogą ujawniać większe niż w przypadku populacji ogólnej trudności w sprostaniu wymaganiom szkoły"7. Stąd też konieczność uwzględnienia możliwości i ograniczeń dziecka oraz szkoły. Każda z propozycji form kształcenia uczniów z niepełnosprawnością (klasa w szkole specjalnej, klasa integracyjna, klasa w szkole ogólnodostępnej) opisywana jest przez pryzmat jej mocnych i słabych stron ${ }^{8}$. Dla podjęcia decyzji konieczna jest odpowiedź na pytanie, co najważniejsze jest dla dziecka, a co ważne dla rodzica, jeśli chodzi o funkcjonowanie dziecka w środowisku szkolnym, w jego edukacji? Być może funkcja wychowawcza szkoły jest istotniejsza niż edukacyjna, choć to może brzmieć paradoksalnie? Być może zdobycie umiejętności społecznych będzie ważniejsze niż nabycie wiedzy i umiejętności typowo szkolnych? Odpowiedź na te pytania niewątpliwie przysłuży się trafności wyboru formy kształcenia dziecka z niepełnosprawnością.

Rodzicielskie wybory formy kształcenia dziecka z niepełnosprawnością w świetle badań własnych

${ }^{6}$ D. Apanel, Teoria i praktyka kształcenia integracyjnego osób z niepetnosprawnościa w Polsce w latach 1989-2014, Oficyna Wydawnicza „Impuls”, Kraków 2017, s. 10.

7 I. Chrzanowska, op. cit., s. 533.

8 Por. Ibidem, s. 532-591; A. Zamkowska, Wsparcie edukacyjne uczniów z upośledzeniem umysłowym w stopniu lekkim w różnych formach ksztatcenia na I etapie edukacji, Politechnika Radomska, Wydawnictw, Radom 2009, s. 21-54; A. Zamkowska, M. Snopek, Rozwój kompetencji nauczyciela wspomagającego ucznia z autyzmem, „Edukacja Ustawiczna Dorosłych” 2017, nr 3, s. 95-105; J. Lipińska-Lokś, Edukacja uczniów z niepetnosprawnościa - możliwości i ograniczenia, [w:] pedagogika wczesnoszkolna. Uczeń i nauczyciel w zmieniajacej się przestrzeni społecznej, red. I. Kopaczyńska, M. Magda-Adamowicz, M. Nyczaj-Drąg, Wydawnictwo Adam Marszałek, Toruń 2014, s. $248-264$. 


\section{Przedmiot, metoda i technika badań oraz badana grupa}

Przedmiotem diagnozy uczyniono opinie i doświadczenia rodziców w obszarze wyboru przez nich formy kształcenia dla dziecka z niepełnosprawnością. Ustalono także uwarunkowania ich decyzji oraz określono poziom trafności wyboru, dzięki dokonanej przez rodziców ocenie danej formy kształcenia dziecka.

W badaniach odwołano się do dotychczasowych decyzji i aktualnych opinii rodziców uczniów uczęszczających do różnych form kształcenia specjalnego (klasy w szkole specjalnej, klasy integracyjnej w szkole powszechnej, klasy w szkole powszechnej; pojedynczy uczniowie realizowali nauczanie indywidualne). Łącznie diagnozą objęto 15 rodziców (12 matek i 3 ojców, w wieku od 30 do 61 lat $^{9}$, legitymujących się zróżnicowanym poziomem wykształcenia, charakteryzujących się różną sytuacją rodzinną) uczniów z niepełnosprawnością ${ }^{10}$ uczęszczających do klas IV-VI szkoły podstawowej. Badania miały miejsce w latach 2015-2017 w szkołach na terenie Zielonej Góry.

Zrealizowane badania miały charakter badań jakościowych. Zastosowano $\mathrm{w}$ nich metodę indywidualnych przypadków i technikę wywiadu wystandaryzowanego. Przedstawione wyniki stanowią tylko fragment szerszych badań dotyczących funkcjonowania uczniów z niepełnosprawnością w środowisku szkolnym.

\section{Wyniki badań}

W życiu rodzica mają miejsce ważne dla niego momenty wyznaczane etapami rozwoju jego dziecka: pierwsze słowo wypowie-

${ }^{9}$ Wśród matek uczniów z niepełnosprawnością znalazła się babcia chłopca stanowiąca jego rodzinę zastępczą, stąd tak zaawansowany wiek kobiety udzielającej wywiadu.

10 Uczniowie doświadczali różnych rodzajów i stopnia niepełnosprawności. Dominującą jednak niepełnosprawnością była niepełnosprawność intelektualna w stopniu lekkim. Uczniowie dotknięci byli także niepełnosprawnością sensoryczną (wzroku lub słuchu), niepełnosprawnością ruchową, chorobą przewlekłą. W kilku przypadkach występowała u uczniów niepełnosprawność sprzężona. 
dziane przez dziecko, pierwszy jego krok, pierwszy dzień w przedszkolu czy też pierwszy dzień w szkole, dzień I Komunii św. Wiele z tych ważnych życiowych momentów poprzedzonych jest etapem przygotowań i podejmowania decyzji. Badana jednoznacznie ukazały, że rodzice wśród tych ważnych momentów życia ich i ich dziecka umiejscowili właśnie moment pójścia dziecka do szkoły i kwestię wyboru tej odpowiedniej dla niego formy edukacji. Wypowiedź jednej z matek bardzo wyraźnie to podkreśla:

Jak tylko Mateusz przyszedt na świat, staraliśmy się wszystko planować uwzględniając jego niepetnosprawność. Od początku wiedzieliśmy, że jego szkoła też będzie wybierana pod katem jego stanu zdrowia. Wtaściwie kiedy miat cztery lata już zadecydowaliśmy, że będzie to szkoła integracyjna, po tym jak zobaczyliśmy jak radzi sobie w przedszkolu integracyjnym, (...) do przedszkola integracyjnego byliśmy w 100\% przekonani, że to jest najlepszy wybór (...). Pierwszy dzień $w$ szkole to byto dopiero wydarzenie!

Inna matka wyznała:

Doczekać się nie mogliśmy, strój galowy, tornister już na początku wakacji kupiliśmy, wszystko zaplanowaliśmy, (...). Po rozpoczęciu ro$k u$ wszyscy poszliśmy na uroczysty obiad, babcia i chrzestna aż z Krakowa przyjechaty.

Wielu innych rodziców także podkreśliło znaczenie tego pierwszego dnia w szkole, wskazując jednocześnie na to, że pójście dziecka do szkoły było dowodem na pewną normalność ich życia mimo naznaczenia go niepełnosprawnością dziecka i wieloma wątpliwościami co do osiągnięcia przez dziecko sukcesu edukacyjnego. Szczególnie mocno wybrzmiewała ta kwestia w wypowiedziach rodziców dzieci, które podjąć miały naukę $\mathrm{w}$ formie integracyjnej kształcenia specjalnego:

Poszedtem z synem na rozpoczęcie roku szkolnego, bytem dumny, jak pewnie każdy rodzic pierwszoklasisty... ale ja tak szczególnie... (...) 
bo do normalnej szkoty, jak inne normalne dzieciaki $i$ ich rodzice (...) prosze mnie nie oceniać, walcze z tym wciąż (...) pewnie nigdy nie zaakceptuję tego upośledzenia.

Niejednokrotnie jeszcze rodzice podkreślali, że pójście do szkoły to przecież fakt w biografii dziecka, a wejście w rolę ucznia przez ich dziecko z niepełnosprawnością, to przejaw naturalnego - i nie będzie przesadnym stwierdzenie - normalnego biegu życia. Normalnego? Takiemu myśleniu przyświeca idea normalizacji życia osób z niepełnosprawnością. I w tym momencie należy mieć nadzieję, że jest ona coraz bliższa powszechnemu urzeczywistnianiu. Niemniej jednak sami rodzice wskazali na pewne różnice w przebiegu etapu przygotowania dzieci pełnosprawnych i dzieci z niepełnosprawnością do realizacji obowiązku szkolnego. W opinii rodziców dzieci z niepełnosprawnością częściej muszą udowadniać, że mogą zostać uczniem, poddawani są większej liczbie różnorodnych diagnoz. Orzeka się o ich gotowości szkolnej, o ich kształceniu, o potrzebie kształcenia specjalnego i kwalifikuje do odpowiedniej jej formy. Procedura zapisania ucznia z niepełnosprawnością do szkoły w opinii ich rodziców jest bardziej czasochłonna i złożona oraz wymaga większego zaangażowania się rodzica.

Badani rodzice wielokrotnie podkreślają swe zaangażowanie w sprawy dziecka. Wiedzą, że teoretycznie każdy rodzic powinien przejawiać zainteresowanie sytuacją swego dziecka, jednak w przypadku rodziców dzieci z niepełnosprawnością oceniają to zaangażowanie najczęściej jako większe. Argumentując to, wskazują na następujące kwestie:

- dziecko z niepełnosprawnością wymaga często ciągłej obecności i opieki rodzica, przez co ten "zmuszony” jest do ciągłego towarzyszenia dziecku - bez względu na jego wiek i najczęściej nieadekwatny do niego stopień samodzielności, kosztem nawet rezygnacji z własnej aktywności zawodowej;

- zakres czynności rodzicielskich wobec dziecka z niepełnosprawnością jest szerszy, obejmuje bowiem nie tylko czynności pielęgnacyjne, opiekuńcze, wychowawcze, ale i wymaga 
pozastandardowych wizyt lekarskich, ciągłego, systematycznie realizowanego działania rehabilitacyjnego (prowadzonego samodzielnie i we współpracy z terapeutami);

- posiadanie dziecka z niepełnosprawnością wymaga większych „nakładów finansowych” związanych z jego specyficznymi potrzebami (w zakresie opieki, terapii, a potem i edukacji), co często wiąże się z koniecznością zwiększenia ilości czasu na aktywność zawodową i zarobkowanie przez drugiego rodzica;

- zakres i intensywność działań opiekuńczych i pielęgnacyjnych wobec dziecka z niepełnosprawnością często nie podlegają zasadzie ich zmniejszenia w miarę wzrostu dziecka i jego samodzielności, w związku z czym jego rodzic dłużej odgrywa rolę opiekuna swego dziecka „na pełnym etacie”, ponosi większy wysiłek (fizyczny, psychiczny), częściej narażony jest na przemęczenie i negatywne emocje. Niewątpliwie rodzice dzieci z niepełnosprawnością narażeni są na zespół wypalenia się sił - choć sami nie określają tak swego stanu;

- bycie rodzicem dziecka $\mathrm{z}$ niepełnosprawnością powoduje udział w licznych i różnorodnych sytuacjach specyficznych, wynikających ze stanu zdrowia i rozwoju dziecka, z jego sytuacji życiowej - i siłą rzeczy „zaopiekowanie” ich oraz podejmowanie decyzji, z którymi rodzice dzieci "standardowych" nie muszą się zmierzać lub też te decyzje w przypadku ich dzieci są o wiele prostsze, mniej skomplikowane i czasochłonne.

Rodzice oprócz podnoszenia kwestii swego ogromnego zaangażowania w sprawy dziecka, trudu bycia rodzicem dziecka ze specjalnymi potrzebami, wskazywali także na ogrom odpowiedzialności za dziecko. Doświadczali, że poczucie ich odpowiedzialności nie zmniejsza się w miarę dorastania dziecka. Mówili o ciągłym myśleniu o dziecku, o jego sprawach, o jego przyszłości, która tworzona jest każdego dnia, w każdej decyzji i tej dotyczącej wydaje się błahostki i tej wpływającej na kluczowe elementy biografii podopiecznego. $\mathrm{W}$ opinii rodziców takim znaczącym elementem w życiu dziecka 
jest jego edukacja, wykształcenie - to, co stanowi podłoże dorosłego życia. Rodzice przyznali, że moment pójścia ich dziecka do szkoły wywołał u nich silne emocje. Zdawali sobie sprawę z powagi sytuacji i własnej odpowiedzialności za podjęcie odpowiedniej decyzji w kwestii wyboru nie tylko szkoły dla dziecka, ale przede wszystkim formy jego edukacji. Była to dla nich sytuacja stresowa, w większości przypadków nie czuli się pewnie i bezpiecznie, często towarzyszyły im wątpliwości i - jak to sami niejednokrotnie określali - bezradność i zmęczenie sytuacją trwającą niejednokrotnie za długo (nawet do trzech miesięcy) jak na decyzję tak oczywistą.

Co ciekawe - a jednocześnie zastanawiające i w gruncie rzeczy zatrważające - kilku rodziców nie było świadomych swego prawa decydowania o drodze edukacyjnej dziecka, a kiedy o takim prawie się dowiedzieli, najczęściej potraktowali je jako tylko formalność $\mathrm{w}$ rozmowie ze "specjalistą - urzędnikiem" lub tė̇ nie potrafili $\mathrm{z}$ niego $\mathrm{w}$ sposób $\mathrm{w}$ pełni przemyślany skorzystać, polegając na poradzie innej osoby, głównie pracownika poradni psychologiczno-pedagogicznej:

To chyba nieporozumienie by ktoś, kto się na tym uczeniu dzieci nie zna, miat o nim decydować

lub też pochopnie decyzję podjęli, po czym - zapewne po przemyśleniach czy „ukierunkowaniu” - zmienili ją. Mama Ewy z Zespołem Downa pomyślała, że skoro sama może decydować, to:

zadecyduję tak jak mi na rękę (...) szkote specjalna mam pod nosem, blisko domu, dłużej Ewka pośpi i sama będzie wracać, bo drogę zna, (...) biega tam na boisko czy na festyn.

Inna mama stwierdziła:

Adam zawsze odstawat od innych dzieci. (...) Dostat orzeczenie o kształceniu specjalnym, to wiedziałam, że pójdzie do szkoty specjalnej. (...) Sąsiadka - przedszkolanka - powiedziała, że wcale nie musi do specjalnej, że może do integracyjnej. (...) Może i lepiej - pomyśla- 
łam, bo paluchami nie będa wytykać na podwórku, że wszyscy chodza do $X^{11}$, a on do specjalnej.

Badania ukazały jednak dominację liczebną grupy rodziców, którzy wiedzieli o możliwości decydowania o wyborze formy kształcenia dla swego dziecka. Chcieli tę decyzję podjąć w sposób przemyślany, więc tematem edukacji dzieci z niepełnosprawnością zainteresowali się wcześniej, niejednokrotnie korzystając ze wsparcia w podjęciu decyzji o losie na gruncie edukacji swego dziecka. Bardzo często była to pomoc fachowa, specjalisty. Mama Asi tak stwierdziła:

Podczas terapii rozmawiałam z pania Ania - logopedka, zastanawiatam się jak potem w szkole będzie z terapią. Pani Ania powiedziała, że bez względu na to, jaka to będzie forma edukacji, zawsze Asia będzie mogła mieć dodatkowe zajęcia. Dużo rozmawiatyśmy, nie tylko o tej terapii ale tak ogólnie o szkołach. (...) Pani Ania była takim drogowskazem po tych szkołach (...), ona pomogła w podjęciu decyzji.

Mama Karola z wadą słuchu podjęła decyzję o placówce specjalnej dla syna po rozmowie i sugestiach nauczycielki przedszkola, która przedstawiła wiele argumentów przemawiających za tą formą edukacji, wskazując jednocześnie przykład dorosłej już osoby głuchej, która po edukacji w integracji trafiła do ośrodka dla głuchych i po latach, twierdzi, że ma takie dobre życie, właśnie dzięki skończeniu nauki w ośrodku dla głuchych. Kolejna mama zaznaczyła rolę pracowników poradni psychologiczno-pedagogicznej i nauczyciela ze szkoły w podjęciu przez nią decyzji o edukacji jej przewlekle chorej (epilepsja) córki z niepełnosprawnością intelektualną. $\mathrm{Z}$ kolei mama innej niepełnosprawnej i intelektualnie i ruchowo 12-latki wskazała początkowo na pełną samodzielność w kwestii decyzyjności o edukacji swej córki, pod koniec rozmowy przyznała, że jednak nie była pozostawiona sama sobie, potwierdzając wcześniej przywołane doświadczenie matki dziewczynki z epilepsją:

11 Numer szkoły został zmieniony, podobnie jak i imiona uczniów w trosce o anonimowość badanych. 
Znam zasadę - umiesz liczyć, licz na siebie; poza tym to ja w petni jestem za dziecko odpowiedzialna. (...) No i na studiach byto co nieco o niepetnosprawnych. (...) Coś wiedziałam, ale czasu dużo minęło, pozmieniało się, więc na nowo się dowiadywałam, (...) czytałam mądre książi, odwiedziłam czytelnię pedagogiczna, szukałam w internecie (...). W poradni chyba mieli mnie dość, taka byłam dociekliwa (...). Jak zdecydowałam się na edukacje włączająca, byłam na rozmowie w szkole u dyrektora i pedagoga.

Na korzystanie w podejmowaniu decyzji o edukacji dziecka ze źródeł internetowych wskazywało wielu innych rodzice, którzy odwiedzali fora internetowe, dyskutowali na blogach, poznawali ofertę szkół podczas podróży wirtualnych.

Niemniej jednak rodzice bardziej cenili sobie wyrobienie własnej opinii podczas kontaktu bezpośredniego z innymi rodzicami dzieci z niepełnosprawnością, szczególnie tymi, którzy są lub byli uczniami danej formy edukacji. Wtedy mogli skorzystać z doświadczenia tych rodziców, byli oni ekspertami w interesującej w tym momencie rodzica dziedzinie, odpowiadali na właściwie wszystkie nurtujące go pytania, co pozwoliło rozwiać wiele wątpliwości, mogli się ich poradzić i, co bardzo istotne, mogli:

zobaczyć efekt tej edukacji - jak sobie ten chtopak radzi (...). To mnie przekonato (...) i nie ważne, że ktoś źle myśli o szkole specjalnej.

Płaszczyzną spotkań tych dwóch grup rodziców najczęściej była wspólna przynależność do stowarzyszenia lub cykliczne spotkania podczas zajęć terapeutycznych dziecka w poradni specjalistycznej. Źródłem informacji o edukacji uczniów z niepełnosprawnością i jednocześnie swoistą pomocą w podjęciu przez rodzica decyzji o wyborze formy edukacji dziecka z niepełnosprawnością jest też zapoznanie się z placówką oferującą daną formę edukacji podczas osobistej wizyty rodzica w tej placówce. Rodzice często wskazywali sytuacje („Dni Otwartych Drzwi”, lekcje pokazowe, imprezy integrujące szkołę ze społecznością lokalną), kiedy to trafiali do danej szkoły, by móc ją poznać, by móc samemu przekonać się o jakości 
jej funkcjonowania, by wreszcie obserwując uczniów - odpowiedzieć sobie na pytanie o dobre miejsce ich dziecka w tej szkole.

Badania ukazały długą i krętą drogę rodziców do podjęcia decyzji o wyborze formy edukacji dziecka $\mathrm{z}$ niepełnosprawnością. Dokonując wyboru rodzice byli przekonani o słuszności swej decyzji, wszak tak wiele poświęcili temu wyborowi czasu i zaangażowania. Tak wiele kwestii wzięli pod uwagę, wybierając $\mathrm{w}$ ich mniemaniu najlepszą drogę edukacji dla własnego dziecka. Rodzice wśród uwarunkowań swych wyborów wskazywali na liczne i różnorodne motywy. Warto zaprezentowań wybrane wypowiedzi rodziców, obrazujące najbardziej charakterystyczne przesłanki wskazań:

a) dobro dziecka było dla mnie najważniejsze, jego korzyści z tej szkoły - na tu i teraz, ale i tak ... w perspektywie (...), wyksztatcenie, praca, rodzina;

b) dziecko z niepetnosprawnościa musi się dostosować, musi sobie poradzić (...), by mieć jak najmniej trudności (...) i dziecko i rodzice (...) szkota musi być odpowiednia (...) taka dobra dla ucznia;

c) ja podejmowałem decyzje, (...) żona też - razem - skoro my decydujemy, my ponosimy odpowiedzialność, my decydujemy.

Warto w tym momencie rozwinąć o analizę uzyskane wyniki. Można by rzec, uwarunkowań rodzicielskich wyborów upatrywać należy w trzech aspektach. Pierwszy - dobro dziecka postrzegane jako wartość sama w sobie. I rzeczywiście rodzice wybierają tę formę edukacji, która $\mathrm{w}$ ich przeświadczeniu $\mathrm{w}$ pełni uwzględni potrzeby, możliwości i ograniczenia ich dziecka. Myślą o szkole, która stanie na wysokości zadania, realizując swe funkcje wobec uczniów, także a może przede wszystkim tych z niepełnosprawnością. Ważny dla rodziców jest pobyt dziecka $\mathrm{w}$ przyjaznej dla niego szkole, ale i spoglądają na swój wybór w perspektywie czasowej, oczekując od szkoły przygotowania swego dziecka do dorosłości, do realizacji ról życiowych z niej wynikających. Chcą, by ich syn/córka zdobył(-a) zawód pozwalający na znalezienie pracy. Widzą swe dziecko w otoczeniu własnej rodziny, osób sobie bliskich, będących oparciem $\mathrm{w}$ codziennym życiu. Takie postrzeganie dorosłości swego 
dziecka eliminuje myślenie rodziców o jego marginalizacji czy wykluczeniu społecznemu. Tę motywację należy ocenić jako najbardziej pożądaną. $W$ drugiej zaprezentowanej przesłance rodzicielskiego wyboru widoczna zdaje się być roszczeniowa postawa rodzica, błędna interpretacja założenia edukacji dziecka z niepełnosprawnością. Rzeczywiście to nie dziecko ma się dostosować do wymagań szkoły, to ona ma prawny obowiązek należytej pracy z uczniem o specjalnych potrzebach edukacyjnych. Uczniowi mają być zapewnione warunki, by mógł sobie radzić, mieć jak najmniej trudności. To ma być jednak efekt pracy ucznia, szkoły i rodzica. (...) szkoła musi - być odpowiednia, dobra, nie sprawiać trudności i dziecku i rodzicowi - wypowiada się rodzic, który jawi się jako ten, wiedzący najczęściej najlepiej, niedopuszczający do siebie opinii szkoły i w nauczycielach niedostrzegający partnerów w pracy z dzieckiem, lecz wręcz wrogów, sam z siebie niewiele wnosząc do życia i rozwoju dziecka. W trzecim ujęciu uwarunkowań wyborów rodziców dostrzega się samych rodziców, ich emocje, postawy. Oni decydenci, oni odpowiedzialni - ale za co? Za kogo odpowiedzialni? - pojawia się pytanie. Analiza wielu wypowiedzi rodzica ukazuje niestety niekorzystną sytuację zarówno jego, jak i jego dziecka. Być może brak akceptacji niepełnosprawności dziecka i siebie $\mathrm{w}$ roli rodzica dziecka z niepełnosprawnością skutkuje właściwie troską opiekę dla siebie, nie dziecka. Brak akceptacji sytuacji życiowej, obawa o opinię inny osób narazić może rodzica na podejmowanie błędnych decyzji, które negatywnie wpłynąć mogą nie tylko na jego życie, ale przede wszystkim na funkcjonowanie jego dziecka.

Ta sytuacja, podobnie jak i poprzednia, wymagają swoistej interwencji w chwili obecnej, wcześniej obie wymagały działań o charakterze profilaktyki, by zapobiec niekorzystnym decyzjom i wyborom rodziców. Pierwsza sytuacja, gdzie u podstaw decyzji rodziców leżą rzeczywiste dobro dziecka i właściwe postawy rodzicielskie, warta jest natomiast ukazania jako przykład dobrych praktyk.

Jest to ważne tym bardziej, że badania ukazały pewną zależność między uwarunkowaniami decyzji rodziców o wyborze formy 
kształcenia dziecka i oceną przez nich trafności tych decyzji. Analiza wypowiedzi rodziców: ich opinii i deklaracji doświadczeń wskazuje jednak na niejednoznaczność oceny trafności decyzji o wyborze szkoły dla dziecka. Oto potwierdzające ten wniosek wypowiedzi rodziców:

a) chcieliśmy dobra dziecka i ono jest. (...) Chtopak leci do szkoty jak na skrzydtach. (...) ma kolegów, koleżankę $\odot$, dobrych nauczycieli. (...) Odradzali nam szkołe specjalna, ale my wiedzieliśmy, że każdy ma swoje miejsce - Tomek tez - skoro taki wyjatkowy, to niech i szkoła będzie ... wyjątkowa, specjalna. (...) Stowo honoru to dobra szkoła i dobry nasz wybór;

b) szkota nietrafiona, przereklamowana, gdzie tam otwarta na ucznia (...). Nie chodzimy, bo tam nas nie chca (...), ale i my też ich nie potrzebujemy. Zaraz się skończy (...). I święty spokój! (...) źle wybraliśmy;

c) dokonaliśmy wyboru, bo mieliśmy takie prawo $i$ ważne byto dla nas żeby nie trafit do szkoty specjalnej. (...) troszkę inaczej sobie to wyobrażaliśmy (...). Klasa integracyjna okazało się, że też przypina etykiete a tego chcieliśmy uniknąć. (...) zastanawiamy sie nad zmiana, może ta inkluzja? (...) To ważne! Znowu pani szuka czegoś! (...) tak dla mnie ważne... (...) Może nie ma najlepszej decyzji $w$ naszej sytuacji.

Dodać należy, że oceny trafności decyzji rodziców dokonano m.in. dzięki analizie ich wypowiedzi oceniających formę kształcenia, do której uczęszcza dziecko. Oceny tej rodzice dokonali uwzględniając następujące kryteria:

a) zgodność propozycji oferty szkoły z jej realizacją - rodzic, dokonując wyboru szkoły, kierował się ofertą szkoły skierowaną do jego dziecka z niepełnosprawnością. Miał wtedy przekonanie, że szkoła posiada odpowiednie możliwości zaspokojenia specjalnych potrzeb edukacyjnych ucznia. Codzienność edukacyjna zweryfikowała poziom zgodności oczekiwań ucznia/jego rodziców i możliwości/ograniczeń szkoły (szczególnie w zakresie kompetencji nauczycieli, zajęć 
dodatkowych specjalistycznych, stosowania odpowiednich metod i środków nauczania oraz dostosowania wymagań do możliwości ucznia);

b) miejsce ucznia w społeczności szkolnej - rodzic oczekuje dla swego dziecka dobrego miejsca w szkole, w klasie wśród rówieśników i w relacji z nauczycielami. Ceni sobie zaangażowanie nauczycieli w sprawy ucznia i ich cechy osobowościowe. Chce by jego dziecko cieszyło się sympatią rówieśników i uczestniczyło w życiu klasy. Cierpi i pragnie zmiany, jeśli jego dziecko źle czuje się w szkole i wśród rówieśników;

c) rodzicielskie poczucie wsparcia w środowisku szkolnym - rodzic postrzega w korzystniejszym świetle szkołę i nauczycieli, jeśli sam czuje się w tym środowisku dobrze, ma przeświadczenie o współdecydowaniu o sprawach szkoły i swojego dziecka. Nie bez znaczenia jest poczucie otrzymywania wsparcia dla swego dziecka i siebie samego w wypełnianiu roli rodzica, $w$ radzeniu sobie $\mathrm{z}$ dzieckiem.

Badania ukazały zróżnicowanie w przebiegu procesu podejmowania przez rodziców decyzji o wyborze formy kształcenia dziecka z niepełnosprawnością, finałem tych decyzji jest uczęszczanie dzieci do różnych form kształcenia specjalnego. Wyniki badań wskazały na liczne i różnorodne uwarunkowania decyzji - wyboru formy kształcenia dziecka. Pozwoliły na wnioskowanie o zróżnicowanej, ale i niejednoznacznej ocenie trafności podjętej decyzji - wyboru drogi edukacyjnej dziecka.

\section{Podsumowanie}

Niewątpliwie sytuacja podjęcia przez rodzica decyzji o wyborze formy kształcenia dziecka jest trudna i złożona. Sami rodzice nie czują się przygotowani do jej podjęcia. Brakuje im wsparcia w tym zakresie. Pojawia się więc refleksja: kto, gdzie, w jakim zakresie i w jaki sposób powinien tego wsparcia rodzicom udzielać? Zawsze będą oni szukać informacji na własną rękę - dobrze, jeśli ją uzyskają 
od specjalisty, osoby kompetentnej, posiadającej rzetelną wiedzę w danym obszarze i posiadającej umiejętności radzenia człowiekowi $\mathrm{w}$ trudnej dla niego sytuacji. To wsparcie informacyjne jest konieczne, bez niego dane do zadania, jakim jest wybór - nie będą pełne, więc i sam wybór może nie być prawidłowy. Szczególnego znaczenia nabiera informowanie o unormowaniach prawnych, zapisanych $w$ nich prawach i obowiązkach. Nieznajomość prawa stanowi istotną przeszkodę $\mathrm{w}$ funkcjonowaniu. Stanowi zagrożenie $\mathrm{w}$ wymiarze indywidualnym, rodzinnym i społecznym.

Nie bez znaczenie jest też wsparcie emocjonalne rodzica, wszak sytuacja podejmowania decyzji i idących za nią konsekwencji w postaci zmiany jest sytuacją trudną. Sytuacja taka pociąga za sobą poczucie deprywacji, zagrożenia, przeciążenia. Rodzic $w$ tej sytuacji potrzebuje wsparcia $\mathrm{w}$ pokonaniu sytuacji trudnej, $\mathrm{w}$ poradzeniu sobie $\mathrm{z}$ negatywnymi własnymi emocjami i $\mathrm{w}$ dokonaniu racjonalnego osądu sytuacji i podjęciu trafnych decyzji.

Ogromne wyzwanie przed szkołami i poradniami, w mury których trafia/ma trafić uczeń $\mathrm{z}$ niepełnosprawnością i jego rodzic. Skoro tak ważne dla rodzica jest poczucie wsparcia w kluczowych momentach życia własnego i swego dziecka, to placówki te powinny zapewnić jemu i dziecku odpowiednie miejsce $w$ systemie pomocowym. Nie jest to kwestią nową, wszak współpraca z rodzicami stanowi jedno z najważniejszych zadań nauczyciela i całego zespołu specjalistów zajmujących się dzieckiem. Jest to jednak zadanie na tyle trudne, że wymaga pokłonienia się nad jego realizacją. Istnieje jednocześnie potrzeba rozszerzenia zakresu współpracy, na co wskazują obie strony i nauczyciele, specjaliści, i rodzice dzieci ${ }^{12}$.

12 Por. P. Plichta, I. Jagoszewska, J. Gładyszewska-Cylulko, B. Szczupał, A. Drzazga, B. Cytowska, Specjalne potrzeby edukacyjne uczniów z niepetnosprawnościami. Charakterystyka, specyfika edukacji i wsparcie, Oficyna Wydawnicza "Impuls”, Kraków 2017, s. 188-189; Ksztatcenie uczniów z niepetnosprawnościami o specjalnych potrzebach edukacyjnych. Informacja o wynikach kontroli, NIK, KNO-4101-01-00/2012, Warszawa 2012, s. 54-55; Z. Gajdzica, Sytuacje trudne w opiniach nauczycieli klas integracyjnych, Oficyna Wydawnicza „Impuls”, Kraków 2011, s. 179-181. 


\section{Bibliografia}

Apanel D., Teoria $i$ praktyka kształcenia integracyjnego osób z niepetnosprawnościa w Polsce w latach 1989-2014, Oficyna Wydawnicza „Impuls”, Kraków 2017.

Chrzanowska I., Pedagogika specjalna. Od tradycji do wspótczesności, Oficyna Wydawnicza „Impuls”, Kraków 2015.

Gajdzica Z., Sytuacje trudne w opiniach nauczycieli klas integracyjnych, Oficyna Wydawnicza „Impuls”, Kraków 2011.

J. Lipińska-Lokś, Edukacja uczniów z niepetnosprawnościa - możliwości i ograniczenia, [w:] Pedagogika wczesnoszkolna. Uczeń i nauczyciel w zmieniającej się przestrzeni społecznej, red. I. Kopaczyńska, M. Magda-Adamowicz, M. Nyczaj-Drąg, Wydawnictwo Adam Marszałek, Torun 2014.

Kształcenie uczniów z niepetnosprawnościami o specjalnych potrzebach edukacyjnych. Informacja o wynikach kontroli, NIK, KNO-4101-01-00/2012, Warszawa 2012.

Plichta P., Jagoszewska I., Gładyszewska-Cylulko J., Szczupał B., Drzazga A., Cytowska B., Specjalne potrzeby edukacyjne uczniów z niepetnosprawnościami. Charakterystyka, specyfika edukacji i wsparcie, Oficyna Wydawnicza „Impuls”, Kraków 2017.

Zamkowska A., Snopek M., Rozwój kompetencji nauczyciela wspomagającego ucznia $z$ autyzmem, „Edukacja Ustawiczna Dorosłych” 2017, nr 3.

Zamkowska A., Wsparcie edukacyjne uczniów z upośledzeniem umysłowym w stopniu lekkim w różnych formach kształcenia na I etapie edukacji, Politechnika Radomska, Wydawnictwo, Radom 2009. 